\title{
EFFECT OF THE TiBN COATING ON A HSS DRILL WHEN DRILLING THE MA8M Mg ALLOY
}

\author{
VPLIV TIBN PREVLEKE NA HSS SVEDRU PRI VRTANJU MA8M \\ Mg ZLITINE
}

\author{
Faruk Karaca', Bünyamin Aksakal ${ }^{2}$ \\ ${ }^{1}$ Firat University, Technology Faculty, Dept. Mech. Eng., Elazig, Turkey \\ ${ }^{2}$ Yildiz Technical University, Faculty of Chemical and Metallurgy, Dept. Metallurgy and Mater. Eng., Istanbul, Turkey \\ fkaraca@firat.edu.tr \\ Prejem rokopisa - received: 2014-11-30; sprejem za objavo - accepted for publication: 2015-01-28
}

doi:10.17222/mit.2014.290

\begin{abstract}
$\mathrm{Mg}$ alloy MA8M is used in the aerospace and food industries and in biomedical applications due to its lightness and biocompatibility. This paper presents the drilling performance of the standard HSS and TiBN-coated drill bits during the machining of the MA8M Mg alloy at various drill rotational speeds and feed rates. After the experiments, the surface roughness, topography and chip formation were analyzed. Atomic-force microscopy (AFM) and surface profilometer were used for this purpose. It was observed that higher drilling feed rates and drill rotational speeds lead to lower surface-roughness values. TiBN-coated drill bits exhibited undesired surface qualities.

Keywords: MA8M Mg alloy, TiBN coating, twist drills, surface quality, multiple regression analysis, chip formation
\end{abstract}

Mg zlitina MA8M se uporablja v letalstvu, prehrambeni industriji in v biomedicini, ker je lahka in biokompatibilna. Članek predstavlja obnašanje pri vrtanju z normalnimi HSS in s svedri s TiBN prevleko na konici, pri obdelavi Mg zlitine MA8M pri različnih vrtljajih svedra in hitrostih podajanja. Po eksperimentih je bila analizirana hrapavost površine, topografija in nastanek ostružka. V ta namen sta bila uporabljena mikroskop na atomsko silo (AFM) in profilometer površine. Ugotovljeno je, da večja hitrost podajanja in vrtenja svedra povzroči manjšo hrapavost površine. S TiBN prevlečeni svedri so povzročali neustrezno kvaliteto površine.

Ključne besede: MA8M Mg zlitina, TiBN prevleka, vijačni svedri, kvaliteta površine, multipla regresijska analiza, nastanek ostružka

\section{INTRODUCTION}

Nowadays, reducing the energy consumption and providing a better surface quality in several manufacturing industries are vital for economic production cycles. Many manufacturing industries substituted the materials, e.g., steel was replaced with light metals or plastics to decrease the energy consumption and/or increase the strength/weight ratio. Although light metals such as aluminum or magnesium are easier to machine, the magnesium alloys have a higher specific strength and stiffness than aluminum alloys. ${ }^{1-3}$ Metallic implants made of stainless steel, titanium or cobalt-chromium alloys are used for stress shielding and revision surgeries, improving the quality of life and the healthcare system. On the other hand, due to their low density and compatibility, magnesium alloys are also very promising as orthopedic biomaterials compared to the other metallic alloys such as stainless steel and titanium alloys. ${ }^{4}$ However, the unsatisfactory corrosion resistance of magnesium alloys limit their application to a great extent. ${ }^{5}$

To overcome these undesired problems, in some studies, the microstructures and mechanical properties of magnesium alloys were processed with cyclic closed-die forging. Using this method under various processing conditions resulted in the desired grain size, microstruc- tural parameters and growth mechanical properties. ${ }^{3}$ The surface integrity of a machined magnesium alloy used for biomedical implants could have a critical impact on its corrosion resistance. The influence of the cutting edge radius and the cooling method on the surface integrity was investigated. Cryogenic machining using a large edge-radius tool led to a thicker grain-refinement layer that remarkably enhanced the corrosion performance of the magnesium alloy. ${ }^{5}$ During another surface-integrity treatment, synergistic dry cutting/finish burnishing of magnesium-calcium implants resulted in a good surface finish, high compressive hook-shaped, low-residual stress profile and extended strain hardening of the subsurface with little change in the grain size. ${ }^{4}$

The high-speed dry-machining process investigated with a finite-element model predicts that the most hazardous outcome, the chip ignition during machining magnesium alloys, does not occur during high-speed dry cutting with sharp PCD (polycrystalline diamond) tools. ${ }^{6}$ The effect of coated drills on the minimum-quantitylubrication drilling of magnesium alloys was experimentally investigated using a carbon-coated HSS drill and the AZ91 magnesium alloy. Such a coating and the minimum-quantity-lubrication condition limited the temperature to below the hazardous level and, hence, 
both the drill wear and the magnesium adhesion were successively reduced. ${ }^{7}$ On the other hand, the machining of the AZ91 magnesium alloy with both the TiN-coated and PCD tools was conducted to find the influence of tool coatings in the machining of magnesium. It showed an excessive tool wear of the TiN carbides even at low cutting speeds, while the PCD coatings showed better results at low film thicknesses. ${ }^{1}$

A limited number of the investigations were performed in the field of machinability of magnesium alloys. In this study, experimental drilling of the MA8M magnesium-alloy sheet was conducted. The effects of the drilling parameters such as the drill speed, the diameter, the feed rate and the TiBN coating on the hole-surface quality were analyzed with respect to the surface roughness, the burr and chip formation and the hole accuracy. After these evaluations, the optimum surface quality was determined. I was also found that an increased drill feed rate increased the roughness, an increased drill speed decreased the roughness and the TiBN coating increased the surface roughness. The present study could be referenced to similar studies.

\section{EXPERIMENTAL WORK}

In this study, MA8M Mg-alloy sheets having dimensions of $100 \times 100 \times 8 \mathrm{~mm}^{3}$ were used. Two different kinds of the cutting-tool material, namely HSS and TiBN-coated HSS twist drills were used to compare their effects on the surface roughness of the machined holes and the chip formation. Some pilot experiments were performed. Since the best results were obtained with a 6-mm drill diameter of the HSS tools, the TiBN coating was considered only with this diameter and the others were ignored. The tool diameter, feed rate and rotational speed of the cutting tool were changed to explore their effects. A full factorial experimentation was applied

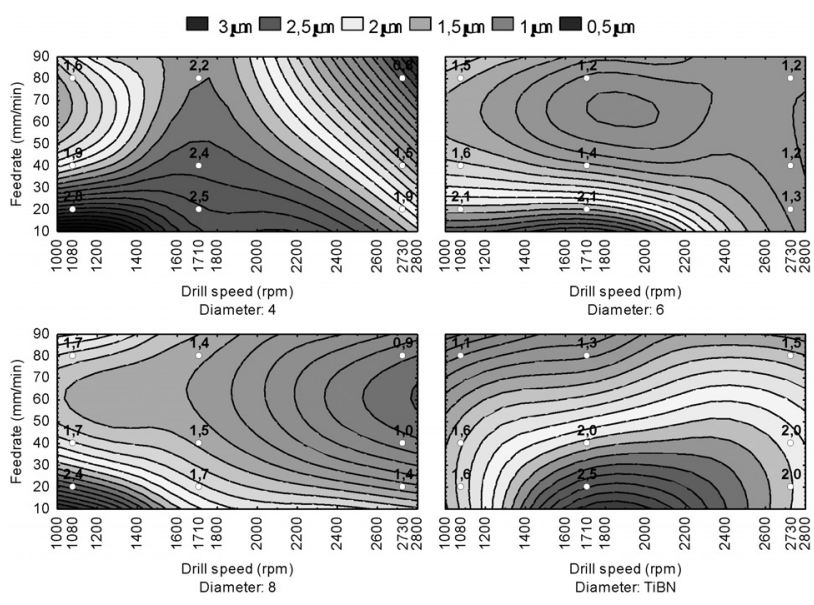

Figure 1: Variation in surface roughness with feed rate, drill speed, drill diameter, in comparison with TiBN-coated drill bits

Slika 1: Spreminjanje hrapavosti površine s podajanjem, hitrostjo vrtenja svedra, premerom svedra, v primerjavi s svedrom $\mathrm{s}$ TiBN prevleko using the parameters. In order to statistically identify the correlation between the applied parameters and the surface roughness, the multiple-regression-analysis method with a confidence interval of $p=0.05$ was used. The drill-bit coating parameter variation of the regression was analyzed separately. The surface-roughness measurements were performed with a Mitutoyo SJ 210 profilometer with a $0.5 \mathrm{~mm} / \mathrm{s}$ measuring speed and 0.25 $\times 4 \mathrm{~mm}$ length in line with the ISO 1997 standard. The average surface roughness $R_{\mathrm{a}}(\mu \mathrm{m})$ was used to evaluate the hole-surface roughness after the measurements were repeated three times. Furthermore, an atomic force microscope (AFM) was used to determine the 3D surface topography with a scanning area of $40 \times 40 \mu \mathrm{m}^{2}$ and a rate of $0.15 \mathrm{~Hz}$ (Park System XE-100).

\section{RESULTS AND DISCUSSION}

The surface roughness, surface topography, chip formations and drill-bit coating were under consideration when evaluating the machinability characteristics of the MA8M Mg alloy. The measured values are discussed in the following sections.

\subsection{Average surface roughness $\left(R_{\mathrm{a}}\right)$}

The surface integrity is an important parameter in machinability and is directly related to the surface roughness. ${ }^{4,5}$ The effects of all the experimental parameters including the drill diameter, the feed rate, the drill speed and the drill coating on the hole-surface roughness, analyzed in a body with contour graphics, are given in Figure 1. In order to plot these contour graphics, the weighted least square method was used. As seen in Figure 1, the surface roughness of the machined holes has a tendency to decrease with an increase in the feed rate for all drill types. When three drill diameters were evaluated, the maximum surface roughness was obtained at a 4-mm drill diameter, while $6-\mathrm{mm}$ and $8-\mathrm{mm}$ drills presented similar values. The roughness reached the highest values at $1710 \mathrm{~min}^{-1}$ when the 4-mm-diameter drill bit was used and then became reduced at 2730 $\min ^{-1}$, as shown in Figure 1.

On the other hand, the TiBN-coated HSS drill bit enhanced the surface roughness to the highest rates (Figure 1) compared to the other three drill bits. There was a significant difference in the roughness between the holes drilled with the TiBN-coated and uncoated 6-mm drill bits. On the other hand, the roughness was reduced with the increased drill diameter when the contour graphics were analyzed. However, a drill speed of 1080 $\mathrm{min}^{-1}$ caused the lowest roughness as the TiBN coating had an inverse effect on the surface roughness during the drilling of the MA8M alloy. Although the increased drill speed caused a decrease in the surface roughness at all three feed rates and with the 6-mm and $8-\mathrm{mm}$ drills, the surface roughness increased with the TiBN coating as shown in Figure 1. 
The drill speed of $1710 \mathrm{~min}^{-1}$ led to the peak roughness from among the three drill speeds when using the TiBN-coated drill. This speed was suggested as a switch point aspect for the surface roughness (Figure 1). Especially the rates of $80 \mathrm{~mm} / \mathrm{min}$ and $40 \mathrm{~mm} / \mathrm{min}$ exhibited similar roughnesses with all three drill speeds. The peak value of the surface roughness $(2.84 \mu \mathrm{m})$ occurred at the speed of $1080 \mathrm{~min}^{-1}$, the feed rate of $20 \mathrm{~mm} / \mathrm{min}$ and the diameter of $4 \mathrm{~mm}$, as shown in Figure 1. The drill speed, feed rate and diameter were also presented as rather parallel results when statistically analyzed. The drill speed had the maximum effect on the surface roughness when partial correlation values of the three parameters were analyzed. The partial correlation values identifying the effectiveness of the drill speed, the feed rate and the diameter were $R_{\text {part }}($ speed $)=-0.62, R_{\text {part }}($ force $)=-0.45$ and $R_{\text {part }}$ (dia.) $=-0.29$, respectively. Statistical results confirmed the above contour plots of the experiment. The most effective parameter was the drill speed, and the least effective parameter was the diameter of the drill bit, also resulting from multiple regressions.

It was established with the analysis that the surface roughness increased with a decreased drill diameter. When $\mathrm{Mg}$ alloys are machined in a dry drilling condition, a flank build-up occurs on the cutting tool and the workpiece due to the adhesion. ${ }^{1}$ The flank build-up formation on the $\mathrm{Mg}$ alloys causes sufficient temperature at the tool-workpiece contact and the adhesion of the workpiece material on the cutting tool leads to an increased cutting-edge radius and to an increase in the machining forces. ${ }^{1,8}$ The flank build-up formation, in the current study, increased the cutting forces and, hence, the performance of the cutting tool was reduced. This suggests that the smallest drill diameter was not enough to sufficiently overcome the cutting forces and a drilling failure occurred. On the other hand, the largest drill diameter was found to be more successful at removing the chips, resulting in a lower surface roughness. In order to achieve smooth surfaces when drilling MA8M, both higher drill speed and feed rate were required.

\subsection{TiBN Coating}

In the present study, the surface roughness was increased to a specific value at a drill speed of $1710 \mathrm{~min}^{-1}$, and then it was diminished with the increasing drill speed up to $2730 \mathrm{~min}^{-1}$. The cutting energy exceeded the plastic-deformation force of the chip and a more effective drilling can be the reason for this fact. Moreover, it was reported that higher cutting temperatures obtained with higher cutting speeds cause material softening on the shear plane, easier cuts and a smoother machined surface. ${ }^{4,9,10}$ Hence, the maximum drill speed of 2730 $\mathrm{min}^{-1}$ caused a decrease in the surface roughness after the peak value reached at $1710 \mathrm{~min}^{-1}$. On the contrary, for the TiBN coating, the critical level of the roughness did not distinctly differ from the uncoated drill bits. According to the general trend, a roughness decrease was observed via the increased drill speed. On the other hand, the surface roughness was increased with a decreased feed rate under all experimental conditions.

Larger cutting forces act more effectively in closing surface cracks and pores. However, there is a limit to the positive effect of the rolling force and beyond certain levels, such a force acts as the initiating source of cracks and cold welds, deteriorating the surface. ${ }^{4}$ However, the TiBN coating had a minor effect on the surface-roughness increment that was also found with the statistical analysis (the partial correlation of 0.2745 ). On the other hand, the feed rate had an extremely strong effect (the partial correlation of -0.66) on the surface-roughness reduction when compared with the drill speed and the coating. In the present study, the TiBN coating of HSS did not have the desired effect on the surface quality because of a lower wear resistance. As the $\mathrm{Mg}$ alloys caused the tool wear of the TiN-coated cutting tools, as reported before, ${ }^{1,11}$ this approach had similar effects on the MA8M drilling operation.

\subsection{Chip formation}

The achievement of a successful and better drilling operation is also indicated by removed chip formations. Moreover, the chip formations can show some variations due to the workpiece material and operation parameters such as cutting speed, feed rate or depth of cut. ${ }^{12}$ For instance, when a regular broken chip or an irregular broken chip is formed on a workpiece with elastic properties, no chip breakers should be provided. Similarly, a workpiece material with elastoplastic properties produces a continuous fragmentary chip or a continuous chip with a wedge-shaped texture, and if the workpiece has plastic properties then the result is a continuous type of chip. ${ }^{12}$ Long chips are usually not desirable because they can tangle along the drill body and have to be removed manually. ${ }^{13}$ Instead, well broken chips are associated with a smooth drilling process.

The diameter slightly influenced the chip formation, and it seemed that a larger diameter provided for a better chip formation. The feed rate seemed a more effective parameter than the drill diameter. Most of the continuous and a few irregular small-particle chips were produced when the TiBN-coated drill bits were used. The analysis suggests that the TiBN coating spoiled the drilling-process performance and the hole quality, which was also confirmed by the chip formation. The chip-formation impairment was derived from an unstable material adhesion on the drill, i.e., the surface roughness was increased by the TiBN coating. Higher drill speeds caused longer chip lengths and higher radii of helical spirals caused flutes that made it hard to drill and hard to push the chips away. Small-string chips are presented in Figure 2a obtained with drilling at the speed of 1080 $\mathrm{min}^{-1}$, the 4-mm diameter and the 40- $\mathrm{mm} / \mathrm{min}$ feed rate.

By comparing Figure 2b with Figure $\mathbf{2 a}$ and by keeping the other parameters constant, it is seen that the 


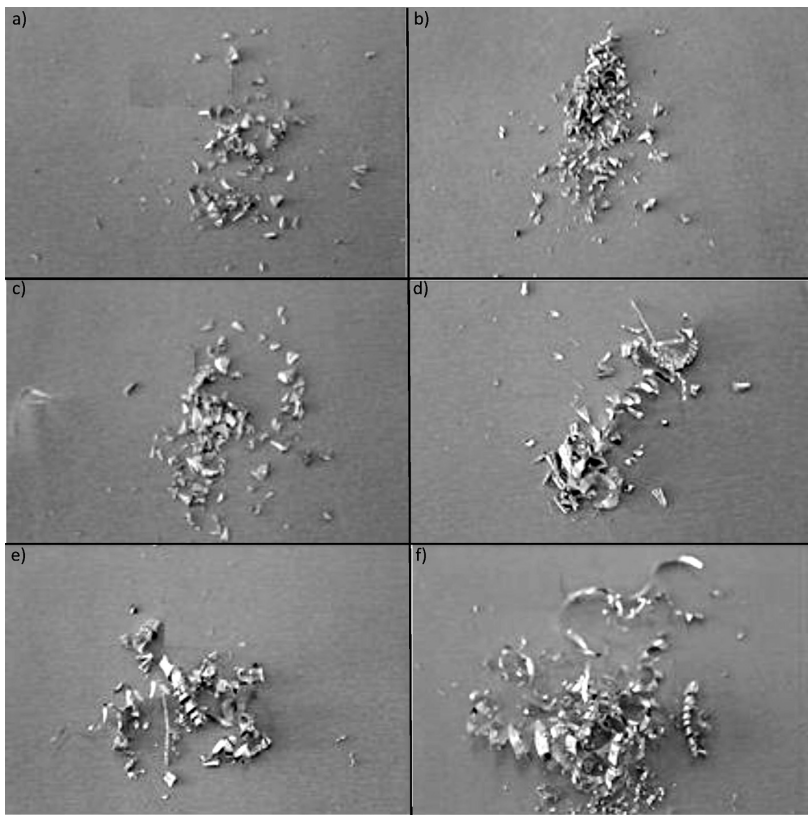

Figure 2: Chip formations for drilling conditions of: a) $1080 \mathrm{~min}^{-1}$ $4 \mathrm{~mm}$ dia and $40 \mathrm{~mm} / \mathrm{min}$ feed rate, b) $1080 \mathrm{~min}^{-1}, 6 \mathrm{~mm}$ dia and $40 \mathrm{~mm} / \mathrm{min}$ feed rate, c) $1080 \mathrm{~min}^{-1}, 6 \mathrm{~mm}$ dia and $80 \mathrm{~mm} / \mathrm{min}$ feed rate, d) $1080 \mathrm{~min}^{-1}, 6 \mathrm{~mm}$ dia, $80 \mathrm{~mm} / \mathrm{min}$ feed rate by TiBN-coated drill bits, e) $1710 \mathrm{~min}^{-1}, 6 \mathrm{~mm}$ dia, $80 \mathrm{~mm} / \mathrm{min}$ feed rate by TiBN-coated drill bits, f) $2730 \mathrm{~min}^{-1}, 6 \mathrm{~mm} \mathrm{dia}, 80 \mathrm{~mm} / \mathrm{min}$ feed rate by TiBN-coated drill bits

Slika 2: Nastanek ostružkov pri pogojih vrtanja: a) $1080 \mathrm{~min}^{-1}, 4 \mathrm{~mm}$ premera in hitrostjo podajanja $40 \mathrm{~mm} / \mathrm{min}$, b) $1080 \mathrm{~min}^{-1}$, premer $6 \mathrm{~mm}$ in hitrost podajanja $40 \mathrm{~mm} / \mathrm{min}$, c) $1080 \mathrm{~min}^{-1}$, premer $6 \mathrm{~mm}$ in hitrost podajanja $80 \mathrm{~mm} / \mathrm{min}$, d) $1080 \mathrm{~min}^{-1}$, premer $6 \mathrm{~mm}$ in hitrost podajanja $80 \mathrm{~mm} / \mathrm{min}$ pri svedru s TiBN prevleko, e) $1710 \mathrm{~min}^{-1}$, premer $6 \mathrm{~mm}$ in hitrost podajanja $80 \mathrm{~mm} / \mathrm{min}$ pri svedru s TiBn prevleko, f) $2730 \mathrm{~min}^{-1}$, premer $6 \mathrm{~mm}$ in hitrost podajanja $80 \mathrm{~mm} / \mathrm{min}$ pri svedru s TiBN prevleko

smaller and irregular chips occurred as the drill diameter changed from $4 \mathrm{~mm}$ to $6 \mathrm{~mm}$. Since the drill diameter was changed exclusively from $4 \mathrm{~mm}$ to $8 \mathrm{~mm}$, a slight difference was observed in the chip formation (Figures $\mathbf{2 a}$ and $\mathbf{2 b}$ ). An insignificant difference in the chip formation was observed when Figures $\mathbf{2 b}$ and $\mathbf{2 c}$ were compared, being almost identical with Figure 2a. Obviously,

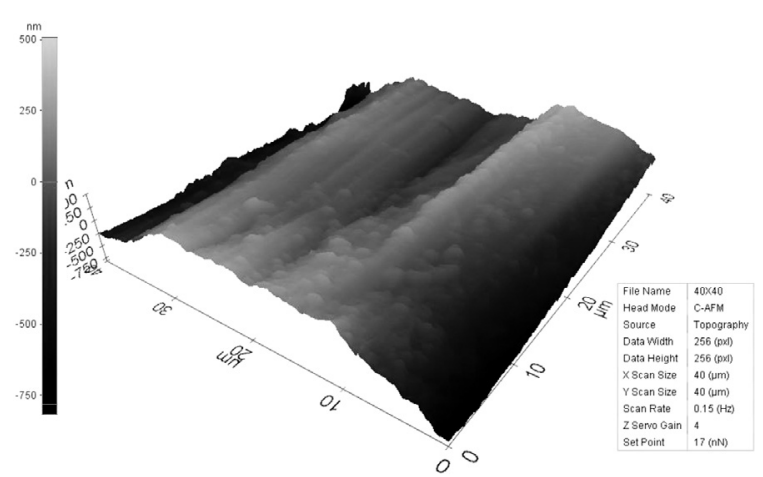

Figure 3: AFM topography of a specimen drilled at $1710 \mathrm{~min}^{-1}, 6 \mathrm{~mm}$ and $40 \mathrm{~mm} / \mathrm{min}$

Slika 3: AFM-topografija vzorca, vrtanega pri $1710 \mathrm{~min}^{-1}, 6 \mathrm{~mm}$ in $40 \mathrm{~mm} / \mathrm{min}$

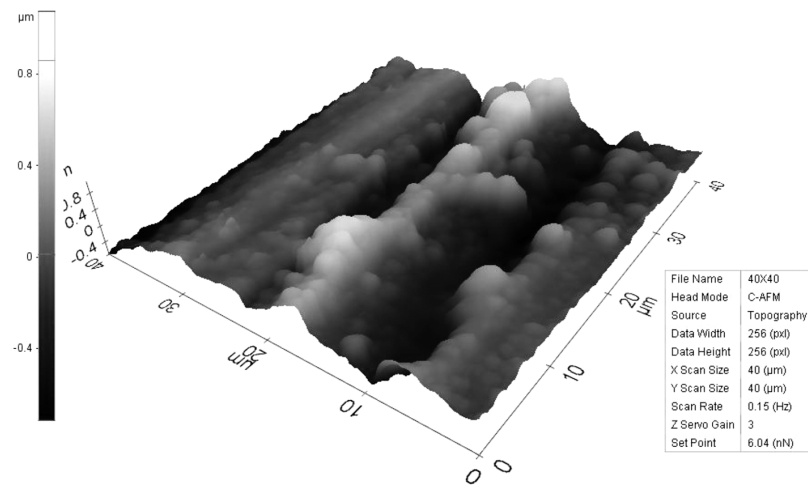

Figure 4: AFM topography of a specimen drilled at $2730 \mathrm{~min}^{-1}, 6 \mathrm{~mm}$ and $40 \mathrm{~mm} / \mathrm{min}$

Slika 4: AFM-topografija vzorca, vrtanega pri $2730 \mathrm{~min}^{-1}, 6 \mathrm{~mm}$ in $40 \mathrm{~mm} / \mathrm{min}$

no significant difference in the chip formation was observed between Figures $\mathbf{2 a}, \mathbf{2 b}$ and $\mathbf{2 c}$. Therefore, the chip formation was not influenced by the drill diameter and the feed rate. Figure 2d shows rather different chip formations formed due to the TiBN coating including a few long helical spiral chips that mostly had short strings. An increased drill speed increased the amount of the long helical spiral chips as seen from Figures 2d, 2e and $\mathbf{2 f}$. Long-string chip formations were obtained especially at $2730 \mathrm{~min}^{-1}$ (Figure 2f) though small-diameter helical chips were observed for the holes drilled at 1710 $\mathrm{min}^{-1}$ (Figure 2e). Irregular, small chip formations presented in Figure $2 f$ are also seen in Figure 2e. In this case, the drill speed and the TiBN coating were observed to be more effective than the feed rate in the chip formation.

\subsection{Atomic-force-microscopy (AFM) observation}

The maximum surface height of $500 \mathrm{~nm}$ was reached (Figure 3). The longitudinal grooves were unclear and shallow when Figures $\mathbf{3}$ to $\mathbf{5}$ were compared. The drill-speed effect obtained at $2730 \mathrm{~min}^{-1}$, the 6-mm drill diameter and the $40-\mathrm{mm} / \mathrm{min}$ feed rate was clearly observed in both Figures 3 and 4 . The maximum height of

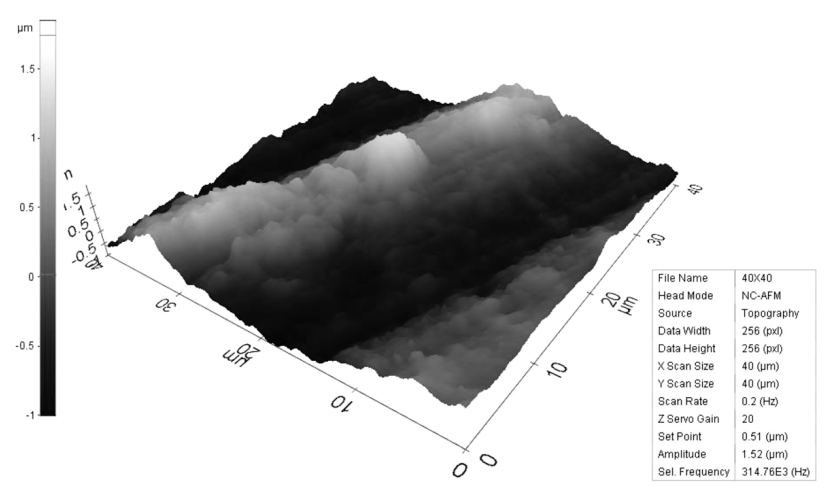

Figure 5: AFM topography of a specimen drilled at $1710 \mathrm{~min}^{-1}$ and $40 \mathrm{~mm} / \mathrm{min}$ with a TiBN-coated drill

Slika 5: AFM-topografija vzorca, vrtanega pri $1710 \mathrm{~min}^{-1}$, s TiBN prevleko in $40 \mathrm{~mm} / \mathrm{min}$ 
the surface was elevated at about $1000 \mathrm{~nm}$, and the longitudinal grooves are clearly seen in Figure 4. The TiBN-coating effect on the surface topography was observed at about $1750 \mathrm{~nm}$, being measured as the maximum height and rare longitudinal grooves of the surface (Figure 5). The drill speed and feed rate were 1080 $\mathrm{min}^{-1}$ and $20 \mathrm{~mm} / \mathrm{min}$, respectively, and the lowest level of the present experimental study led to the surface topography of Figure 5. When Figures $\mathbf{3}$ to $\mathbf{5}$ are compared it is found that the drill speed and TiBN coating had an excessive negative effect on the surface topography during the drilling of the MA8M Mg alloy. On the AFM graphs, the maximum undulation was observed for the TiBN-coated drill.

\section{CONCLUSION}

The experimental work and the analysis showed that the MA8M alloy has a lower machinability capacity. Although the drill-speed increasing was performed rather well, the results for the roughness and chip formation were not obtained with the AFM graphs. The drill speed has a direct relationship with the cutting speed and an increase in the cutting speed resulted in smoother surfaces compared with lower cutting speeds. ${ }^{13}$ But the increment of the cutting speeds led to higher cutting temperatures, and the temperature increase also decreased both the cutting performance of a drill bit and the surface integrity. For this reason, the drill speed should not be performed at extremely high levels. On the other hand, the feed rate can be increased by increasing the drill speed if smooth surfaces are required. However, the feed-rate increment has a positive effect on the surface roughness, and it should be used carefully with smaller diameters of drill bits. According to the results of the experimental work, the TiBN coating was not appropriate for the MA8M drilling operation when compared with the HSS drill bit. However, the wear resistance of the TiBN-coated drilling tools should be investigated.

\section{REFERENCES}

${ }^{1}$ H. K. Tönshoff, J. Winkler, The influence of tool coatings in machining of magnesium, Surface and Coatings Technology, 94 (1997), 610-616, doi:10.1016/S0257-8972(97)00505-7

${ }^{2}$ H. Y. Wu, C. C. Hsu, J. B. Won, P. H. Sun, J. Y. Wang, S. Lee, C. H. Chiu, S. Torng, Effect of heat treatment on microstructure and mechanical properties of the consolidated Mg alloy AZ91D machined chips, J. of Materials Processing Technology, 209 (2009), 4194-4200, doi:10.1016/j.jmatprotec.2008.11.001

${ }^{3}$ W. Guo, Q. Wang, B. Ye, H. Zhou, Microstructure and mechanical properties of AZ31 magnesium alloy processed by cyclic closed-die forging, J. of Alloys and Compounds, 558 (2013), 164-171, doi:10.1016/j.jallcom.2013.01.035

${ }^{4}$ M. Salahshoor, Y. B. Guo, Surface integrity of magnesium-calcium implants processed by synergistic dry cutting-finish burnishing, Procedia Engineering, 19 (2011), 288-293, doi:10.1016/j.proeng. 2011.11.114

${ }^{5}$ Z. Pu, J. C. Outeiro, A. C. Batista, O. W. Dillon, D. A. Jr. Puleo, I. S. Jawahir, Surface integrity in dry and cryogenic machining of AZ31B $\mathrm{Mg}$ alloy with varying cutting edge radius tools, Procedia Engineering, 19 (2011), 282-287, doi:10.1016/j.proeng.2011.11.113

${ }^{6}$ M. Salahshoor, Y. B. Guo, Cutting mechanics in high speed dry machining of bio medical magnesium-calcium alloy using internal state variable plasticity model, Int. J. of Machine Tools and Manufacture, 51 (2011), 579-590, doi:10.1016/j.ijmachtools.2011.04.004

${ }^{7}$ S. Bhowmick, A. T. Alpas, The role of diamond like carbon coated drills on minimum quantity lubrication drilling of magnesium alloys, Surface and Coatings Technology, 205 (2011), 5302-5311, doi:10.1016/j.surfcoat.2011.05.037

${ }^{8}$ Y. H. Celik, Investigating the effects of cutting parameters on the hole quality in drilling the Ti-6Al-4V alloy, Mater. Tehnol., 48 (2014) 5, 653-659

${ }^{9}$ A. Mavi, I. Korkut, Machinability of a Ti-6Al-4V alloy with cryogenically treated cemented carbide tools, Mater. Tehnol., 48 (2014) 4, 577-580

${ }^{10}$ A. Altin, The effect of the cutting speed on the cutting forces and surface finish when milling chromium 210 Cr12 steel hardfacings with uncoated cutting tools, Mater. Tehnol., 48 (2014) 3, 373-378

${ }^{11}$ H. Çaliskan, A. Erdogan, P. Panjan, M. S. Gök, A. C. Karaoglanli, Micro-abrasion wear testing of multilayer nanocomposite TiAlSiN/ TiSiN/TiAlN hard coatings deposited on the AISI H11 steel, Mater. Tehnol., 47 (2013) 5, 563-568

${ }^{12}$ V. P. Astakhov, S. V. Shvets, M. O. M. Osman, Chip structure classification based on mechanics of its formation, J. of Materials Processing Technology, 71 (1997), 247-257, doi:10.1016/S0924-0136 (97)00081-2

${ }^{13}$ K. Feng, J. Ni, D. A. Stephenson, Continuous chip formation in drilling, Int. J. of Machine Tools \& Manufacture, 45 (2005), 1652-1658, doi:10.1016/j.ijmachtools.2005.03.011 